\title{
Pengaruh Social Media Marketing terhadap Intensi Membeli Produk Perawatan Kulit pada Pria
}

\author{
Rafael Hans Christian \& Dewi Syarifah* \\ Fakultas Psikologi Universitas Airlangga
}

\begin{abstract}
ABSTRAK
Penelitian ini bertujuan untuk menguji pengaruh social media marketing terhadap intensi membeli produk perawatan kulit pada pria serta menguji credibility endorser sebagai variabel moderator. Jumlah partisipan penelitian pada penelitian ini sebanyak 131 pria dengan usia minimal 18 tahun. Data pada penelitian ini dianalisis dengan menggunakan pendekatan kuantitatif. Teknik analisis pada penelitian ini adalah analisis korelasi Pearson, analisis linear regression, dan analisis moderasi dengan menggunakan aplikasi Jamovi 1.6.23.0. Hasil penelitian menunjukkan bahwa social media marketing secara umum berpengaruh signifikan terhadap intensi membeli produk perawatan kulit pada pria. Kemudian, hasil analisis moderasi menunjukkan bahwa credibility endorser tidak dapat memoderasi pengaruh customization, interaction dan word of mouth namun credibility endorser dapat memperkuat pengaruh pada dimensi entertainment dan trendiness terhadap intensi membeli.
\end{abstract}

Kata kunci: credibility endorser, intensi membeli, produk perawatan kulit, social media marketing

\begin{abstract}
This study aims to examine the effect of social media marketing on the intention to buy skincare products in men and to test the credibility of the endorser as a moderator variable. The number of research subjects in this study was 131 men with a minimum age of 18 years. The data in this study were analyzed using a quantitative approach. The analysis technique in this study is Pearson correlation analysis, linear regression analysis, and moderation analysis using the Jamovi 1.6.23.0 application. The results showed that social media marketing, in general, had a significant effect on the intention to buy skincare products in men. Then, the results of the moderating analysis show that credibility endorsers cannot moderate the effect of customization, interaction, and word of mouth, but credibility endorsers can strengthen the influence on the dimensions of entertainment and trendiness on purchase intention.
\end{abstract}

Keywords: credibility endorser, purchase intention, skincare products, social media marketing

Buletin Penelitian Psikologi dan Kesehatan Mental (BRPKM), 2021, Vol. 1(2), 1075-1084

*Alamat korespondensi: Fakultas Psikologi Universitas Airlangga, Kampus B Universitas Airlangga Jalan Airlangga 4-6 Surabaya 60286. Surel: dewi.syarifah@psikologi.unair.ac.id

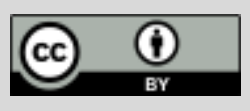

Naskah ini merupakan naskah dengan akses terbuka dibawah ketentuan the Creative Common Attribution License (CC-BY-4.0) (http://creativecommons.org/licenses/by/4.0), sehingga penggunaan, distribusi, reproduksi dalam media apapun atas artikel ini tidak dibatasi, selama sumber aslinya disitir dengan baik. 


\section{PEN D A H U L U A N}

Industri kosmetik dewasa ini merupakan salah satu industri yang mendapatkan banyak profit. Berdasarkan data dari euromonitor international (2016 dalam Abbas, 2017) total nilai global untuk industri kecantikan di seluruh dunia pada tahun 2016 mencapai \$444bn dimana produk perawatan kulit mendominasi pasar industri kecantikan. Dari generasi ke generasi produk kosmetik khususnya skin care merupakan hal yang umum bagi perempuan sehingga target untuk industri ini lebih banyak menyasar kepada perempuan. Namun, seiring berkembangnya zaman, seperti perkembangan dalam bidang ekonomi, sosial, dan teknologi serta ilmu pengetahuan menyebabkan standar hidup meningkat individu menjadi lebih sadar akan pentingnya kesehatan, kecantikan, dan kebersihan. Hal tersebut menyebabkan bertumbuhnya minat pada pria dalam menggunakan produk perawatan kulit (Puspasari \& Aprilianty, 2019).

Di Indonesia sendiri, industri kosmetik pria juga sudah bertumbuh (Puspasari \& Aprilianty, 2019). Data dari Nielsen menunjukkan bahwa kesadaran pria Indonesia untuk menggunakan produk perawatan kulit bertumbuh sebesar 13.5\% dari tahun 2010 hingga 2011, dimana face cleanser, anti-aging dan produk pemutih kulit sebagai produk pertumbuhan tertinggi di pasar (Herdiyanti \& Titus, 2013). Kemudian pertumbuhan tren pemakaian produk perawatan kulit pada pria umumnya terjadi di kotakota besar seperti Semarang, Surabaya, Makassar, Jakarta, Bandung dan Yogyakarta (Ridwan dkk., 2017). Produk-produk grooming seperti produk perawatan kulit telah menarik perhatian kepada perilaku berbelanja pada pria dan sebagai salah satu produk yang wajib untuk dibeli bagi pria (Sanny dkk., 2020). Maka pada penelitian ini, peneliti akan meneliti mengenai produk perawatan kulit pada pria.

Intensi merupakan suatu kecenderungan individu untuk melakukan atau tidak melakukan suatu perilaku tertentu (Ajzen, 1991). Konsumen akan cenderung membeli suatu produk jika konsumen tersebut memiliki intensi untuk membeli produk tersebut. Adapun intensi membeli adalah kecenderungan individu untuk membeli suatu produk tertentu (Ajzen, 1991).

Dalam theory of reasoned action, (Ajzen, 1991) menyebutkan perilaku dapat dipengaruhi oleh sikap dan norma subjektif. Sikap mengacu pada derajat mana seseorang memiliki penilaian evaluasi menguntungkan atau tidak menguntungkan dari perilaku. Kemudian, norma subjektif mengacu pada keyakinan seseorang mengenai pendapat orang lain terhadap dirinya dan tindakan apa yang harus dilakukan. Ferdinand (2006 dalam Isyanto dkk., 2020) menyebutkan faktor yang dapat mempengaruhi intensi membeli salah satunya adalah interest explorative yaitu perilaku individu yang selalu mencari informasi mengenai suatu produk yang membuat individu tertarik. Berkaitan dengan pencarian informasi, saat ini media sosial merupakan salah satu platform untuk mencari informasi berkaitan dengan kegiatan jual-beli. Dalam media sosial, brand dapat memasarkan barangnya untuk menarik pembeli sebaliknya pembeli dapat mencari informasi mengenai barang yang dijual dari brand tertentu dengan melihat official account dari brand tersebut. Kemudian, berdasarkan norma subjetif dari TRA, media sosial dapat menjadi referensi bagi individu dalam mempengaruhi keyakinan individu dalam proses pengambilan keputusan pembelian suatu produk.

Social media merupakan aplikasi berbasis online, platform, atau atau alat mass media yang dapat digunakan untuk memfasilitasi komunikasi, kolaborasi, dan berbagi informasi diantara pengguna dan dapat juga digunakan untuk berjualan serta meningkatkan dan mempertahankan customer (Bilgin, 2018). Tuten \& Salomon (2017 dalam Man \& Rahman, 2019) menyebutkan social media marketing sebagai penggunaan platform media sosial untuk membuat, mengkomunikasikan, menyampaikan dan bertukar penawaran yang memiliki nilai bagi pemangku kepentingan (stakeholder) organisasi. Dewasa

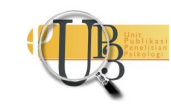


ini, media sosial telah dipakai oleh berbagai perusahaan di dunia untuk berkomunikasi dan berhubungan dengan pelanggan. Seiring dengan perkembangan teknologi terutama dalam bidang komunikasi maka membawa perubahan terhadap strategi perusahaan dalam memasarkan produknya termasuk dalam mengandalkan media sosial sebagai alat marketing perusahaan (Saravanakumar \& SuganthaLakshmi, 2012). Penggunaan media sosial dipercaya menjadi alat marketing yang efektif sebab melalui media sosial perusahaan dapat berkomunikasi secara dua arah, review, serta dapat menguatkan hubungan dengan pelanggan (Tatar \& Eren-Erdoğmuş, 2016).

Dengan semakin banyaknya brand yang memiliki official account di media sosial, memudahkan brand untuk berinteraksi dengan konsumen. Menurut Mikalef, Gianakof, dan Pateli (dalam (Moriansyah, 2015) pada era digital saat ini, media sosial dapat mempengaruhi pengambilan keputusan pelanggan, termasuk keputusan dalam hal membeli sebuah produk. Hal tersebut disebabkan oleh fitur iklan yang dimiliki oleh media sosial sehingga dapat mempermudah perusahaan untuk memasarkan produk yang dijual. Konsumen yang mencari informasi mengenai barang yang akan mereka beli dapat melihat dari paparan atau konten official account brand di media sosial yang dapat mempengaruhi intensi membeli konsumen. Beberapa penelitian sebelumnya telah meneliti mengenai hubungan antara social media marketing dengan intensi membeli. (Kim \& Ko, 2010) menemukan bahwa social media marketing memiliki hubungan dengan intensi membeli pada barang mewah. Kemudian (Laksamana, 2018) juga menemukan bahwa social media marketing memiliki pengaruh terhadap intensi membeli dan brand loyalty.

Perusahaan atau brand tidak hanya menampilkan gambar berupa informasi saja, namun juga berupa iklan atau promosi. Endorsement adalah suatu bentuk promosi yang dilakukan oleh perusahaan yang bekerja sama dengan individu tertentu yang memiliki pengaruh seperti selebriti, influencer, maupun public figure lainnya untuk memasarkan produk dari perusahaan tersebut (Soesatyo \& Rumambi, 2013). Agar suatu pesan tersampaikan dengan baik, maka endorser sebagai spokesperson atau figur perlu memiliki kredibilitas yang cukup untuk mempromosikan produk dengan memiliki pengetahuan, kemenarikan, maupun kepercayaan dari konsumen. Choi \& Rifon (2012) mengatakan bahwa penelitian mengenai efektivitas endorser lebih banyak terkonsentrasi pada kualitas dari endorser itu sendiri (source credibility) atau kecocokan antara produk dan endorser. Figur endorser digunakan oleh brand untuk merepresentasikan produk yang brand tersebut jual. Endorser yang kredibel dapat meningkatkan pesan yang persuasi (Goldsmith dkk., 2000). Hadirnya endorser sebagai sumber atau spokesperson yang dianggap kredibel dapat membuat konsumen lebih yakin terhadap produk-produk yang akan mereka beli sehingga hadirnya endorser yang kredibel dapat membantu dalam meningkatkan minat beli dari konsumen (Gouranga \& Brajesh, 2011). Akses yang cukup mudah melalui media sosial membuat penyampaian pesan dari brand ke konsumen menjadi lebih mudah terjangkau. Selain itu, ditambah dengan adanya endorser sebagai figur atau spokesperson diharapkan dapat menambah dampak dari social media marketing itu sendiri terhadap intensi membeli produk konsumen.

Berdasarkan paparan yang telah dijelaskan diatas, maka pada penelitian ini peneliti akan meneliti apakah figur endorser sebagai spokeperson dari suatu brand di media sosial dapat memperkuat pengaruh dari social media marketing terhadap intensi membeli pada produk perawatan kulit pria.

\section{Intensi Membeli}

Intensi membeli didefinisikan sebagai kecenderungan individu untuk mendapatkan atau membeli suatu produk tertentu (Ajzen, 1991) dan merupakan suatu faktor yang penting untuk mengukut perilaku konsumen. Kotler \& Keller (2016) mengemukakan bahwa intensi membeli adalah bentuk perilaku dari 
konsumen yang memiliki keinginan untuk membeli atau memilih sebuah produk yang didasari oleh pengalaman, penggunaan dan keinginannya pada suatu produk.

\section{Social Media Marketing}

Tuten \& Salomon (2017 dalam Man \& Rahman, 2019) menyebutkan social media marketing sebagai penggunaan platform media sosial untuk membuat, mengkomunikasikan, menyampaikan dan bertukar penawaran yang memiliki nilai bagi pemangku kepentingan (stakeholder) organisasi. (Kim \& Ko, 2010) menyebutkan bahwa dimensi social media marketing adalah entertainment, trendiness, customization, interaction, dan word of mouth.

\section{Credibility Endorser}

Endorser merupakan seorang figur yang digunakan oleh brand dalam sebuah iklan (Mittelstaedt dkk., 2000). Ohanian (1990) menyebutkan credibility sebagai karakteristik dari endorser yang dapat berdampak pada penerimaan pesan konsumen. Kemudian, (Stafford dkk., 2002) mengartikan credibility endorser sebagai salah satu karakteristik komunikator yang positif yang dapat memberikan pengaruh terhadap penerimaan pesan oleh individu. Kredibilitas merupakan tingkat kepercayaan yang dimiliki oleh konsumen terhadap sebuah sumber dalam memberikan informasi terhadap konsumen (Goldsmith dkk., 2000).

Hipotesis dalam penelitian ini adalah:

$\mathrm{H}_{1}$ : Social media marketing marketing secara umum berpengaruh signifikan terhadap intensi membeli

$\mathrm{H}_{2}$ : Credibility endorser dapat memoderasi hubungan entertainment dengan intensi membeli.

$\mathrm{H}_{3}$ : Credibility endorser dapat memoderasi hubungan customization dengan intensi membeli.

$\mathrm{H}_{4}$ : Credibility endorser dapat memoderasi hubungan interaction dengan intensi membeli.

$\mathrm{H}_{5}$ : Credibility endorser dapat memoderasi hubungan word of mouth dengan intensi membeli.

$\mathrm{H}_{6}$ : Credibility endorser dapat memoderasi hubungan trendiness dengan intensi membeli.

\section{MET ODE}

Metode penelitian yang digunakan pada penelitian ini adalah metode kuantitatif dengan tipe penelitian survei. Terdapat tiga variabel yang digunakan pada penelitian ini yang terdiri dari variabel independen, variabel dependen, dan variabel moderasi. Variabel dependen dalam penelitian ini adalah intensi membeli, kemudian variabel independen pada penelitian ini adalah social media marketing dan variabel moderasi pada penelitian ini adalah credibility endorser.

Pada penelitian ini peneliti menggunakan metode non-probability sampling dengan teknik purposive sampling, dimana tidak semua anggota populasi memiliki kesempatan yang sama untuk terpilih menjadi sampel penelitian. Dalam penelitian ini, populasi yang digunakan adalah pria berusia minimal 18 tahun, aktif menggunakan media sosial (Instagram, Twitter, Facebook, Youtube, TikTok) selama kurang lebih 6 bulan terakhir, dan mengetahui produk perawatan kulit. Jumlah partisipan dalam penelitian ini adalah 131 partisipan.

Pada penelitian ini social media marketing diukur dengan menggunakan skala social media marketing milik (Kim \& Ko, 2010). Skala ini terdiri dari 18 item yang terbagi atas lima dimensi yaitu entertainment 4 item, customization 5 item, interaction 4 item, word of mouth 3 item dan trendiness 2 item. Kuesioner

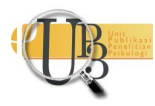


ini disusun menggunakan skala likert dengan lima rentang respon 1 sampai 5. Kemudian, intensi membeli pada penelitian ini diukur dengan menggunakan skala intensi membeli yang diadaptasi dari penelitian (Laksamana, 2018) yang terdiri dari 5 item. Skala intensi membeli disusun dengan skala likert dengan lima rentang respon 1 sampai 5. Selanjutnya, credibility endorser pada penelitian ini diukur dengan mengadaptasi skala credilbility endorser yang dikembangkan oleh (Ohanian, 1990) yang terdiri dari tiga dimensi yaitu attractiveness 4 item, expertise 4 item, dan trustworthiness 4 item. Skala tersebut disusun dengan menggunakan model seven-point semantic differential scales.

Data dalam penelitian ini telah memenuhi uji asumsi untuk analisis regresi. Uji asumsi meliputi uji normalitas residual, uji heteroskedastisitas, uji linearitas, dan uji multikolinearitas. Uji normalitas residual dilakukan dengan melihat normal probability plot. Berdasarkan normal probability plot tersebut didapatkan grafik mendekati garis diagonal yang berarti nilai residual berdistribusi normal. Uji heteroskedastisitas dilakukan dengan melihat data pada scatterplot. Berdasarkan hasil scatterplot, data menyebar dan tidak membentuk pola tertentu sehingga uji heteroskedastisitas terpenuhi. Uji linearitas dilakukan dengan melihat scatterplot dan berdasarkan hasil tersebut data yang dihasilkan adalah linear. Selanjutnya, untuk uji multikolinearitas dilakukan dengan melihat angka toleransi dan angka Variance Inflation Factor (VIF). Apabila nilai toleransi $>0,1$ dan nilai VIF $<10$ maka tidak terdapat masalah multikolinearitas. Semua dimensi variabel bebas dalam penelitian ini menunjukkan nilai toleransi $>0,1$ dan nilai VIF<10 sehingga dapat disimpulkan bahwa tidak terdapat masalah multikolinearitas.

Analisis data pada penelitian ini menggunakan analisis regresi berganda untuk melihat pengaruh social media marketing terhadap intensi membeli secara umum dan partial. Kemudian, peneliti melakukan uji moderasi untuk melihat efek moderasi credibility endorser pada pengaruh setiap dimensi social media marketing terhadap intensi membeli. Proses analisis data pada penelitian ini menggunakan bantuan aplikasi Jamovi 1.6.23.0.

\section{HAS IL PEN ELITIAN}

Hasil analisis deskriptif pada penelitian ini menunjukkan dimensi entertainment memiliki nilai minimum sebesar 5, nilai maksimum sebesar 20, dan perolehan mean sebesar 15,3. Pada dimensi customization nilai minimum sebesar 7 , nilai maksimal sebesar 25, kemudian mean sebesar 20,3. Kemudian pada dimensi interaction nilai minimum sebesar 8, nilai maksimal sebesar 20, dan mean sebesar 25,6. Kemudian pada dimensi WOM nilai minimum sebesar 3, nilai maksimal sebesar 15, nilai mean sebesar 9,53. Lalu, pada dimensi trendiness nilai minimum 2, nilai maksimal 10, dan mean 6,57. Pada dimensi credibility endorser nilai minimum sebesar 38, nilai maksimal 70, dan mean 56,55 dan pada dimensi intensi membeli nilai minimum sebesar 5, nilai maksimum 25, dan mean sebesar 20,15. Nilai skewness dan kurtosis pada setiap variabel menunjukkan angka mendekati 0 yang artinya distribusi data cenderung normal.

Berdasarkan analisis regresi linier berganda, model diketahui cocok dalam menjelaskan data $\left(F(5,125)=14,0 ; p<0,001 ; R^{2}=0.360\right)$ dan varians prediktor dapat menjelaskan 36 persen dari varians variabel dependen, sehingga secara simultan social media marketing dapat memberikan pengaruh sebesar 36 persen terhadap intensi membeli. Kemudian, setelah dilihat pengaruh partial setiap dimensi dari social media marketing, diketahui entertainment $(B=0,4504 ; S E=1,162 ; t=2,775 ; p<0,006)$, customization $(B=0,4293 ; S E=0,141 ; t=3,038 ; p<0,003)$, interaction $(B=-0,0460 ; S E=0,146 ; t=-0,315$; $p<0,753)$, WOM $(B=0,2187 ; S E=0,150 ; t=1,458 ; p<0,147)$, dan trendiness $(B=-0,3951 ; S E=0,235 ; t=-$ $1,681 ; p<0,095)$. Berdasarkan data tersebut, diketahui hanya dimensi entertainment dan customization 
saja yang berpengaruh signifikan terhadap intensi membeli sedangkan interaction, wom, dan, trendiness tidak memiliki pengaruh yang signifikan terhadap intensi membeli.

Berdasarkan tabel uji moderasi diatas dapat dilihat bahwa hasil interaction effect pada model 1 yaitu antara credibility endorser dengan entertainment $(B=0,0201 ; S E=1,1510 ; Z=1,441 ; p<0,150)$ kemudian pada model 2 antara credibility endorser dengan customization $(B=-0,00268 ; S E=0,131 ; Z=-0,204$; $p<0,838)$, pada model 3 credibility endorser dengan interaction $(B=-0,00507 ; S E=0,0129 ; Z=-0,392$; $p<0,695)$, model 4 credibility endorser dengan word of mouth $(B=0,00197 ; S E=0,0129 ; Z=-0,153$; $p<0,879$ ), dan model 5 credibility endorser dengan trendiness $B=-0,0168 ; S E=0,0027 ; Z=-0739 ; p<0,460$ ). Dengan demikian, berdasarkan data tersebut dapat disimpulkan bahwa hasil interaksi setiap dimensi social media marketing dengan credibility endorser tidak signifikan sehingga kemungkinan untuk terjadi efek moderasi sangat kecil.

Kemudian, berdasarkan uji simple slope dapat dilihat bahwa pada model 1 korelasi antara entertainment dengan intensi membeli lebih besar saar credibility endorser tinggi $(+1 \mathrm{SD})$ dengan $(B=0,871 ; S E=0,173$; $Z=-0,5,03 ; p<0,001)$ dibanding saat tingkat credibility endorser rendah $(-1 S D)$ dengan $(B=-0,527$; $S E=0,209 ; Z=-2,52 ; p<0,012$ ). Kemudian, pada model 2 bahwa korelasi antara customization dengan intensi membeli dengan lebih tinggi saat tingkat credibility endorser yang rendah $(-1 S D)(B=0,642$; $S E=0,178 ; Z=-0,3,61 ; p<0,0,001)$ dibanding dengan tingkat credibility endorser yang tinggi $(+1 S D)$ dengan $(B=0,596 ; S E=0,196 ; Z=-0,3,05 ; p<0,002)$ namun perbedaannya sangat trivial. Pada model 3 , korelasi antara interaction dengan intensi membeli baik pada tingkat credibility endorser yang tinggi $(+1 S D)$ dengan $(B=-0,397 ; S E=0,222 ; Z=-1,79 ; p<0,074)$ maupun rendah $(-1 S D)$ dengan $(B=-0,397$; $S E=0,166 ; Z=-2,91 ; p<0,004)$ terlihat sama saja sehingga tidak terjadi efek moderasi. Selanjutnya pada model 4 , korelasi antara word of mouth dengan intensi membeli dengan tingkat credibility endorser yang tinggi (+1SD) dengan $(B=-0,492 ; S E=0,179 ; Z=-2,76 ; p<0,006)$ sedikit lebih besar daripada dengan tingkat credibility endorser yang rendah (-1SD) dengan $(B=0,492 ; S E=0,185 ; Z=-2,49 ; p<0,013)$ namun perbedaanya sangat kecil atau trivial. Terakhir, pada model 5 , korelasi antara trendiness dengan intensi membeli dengan tingkat credibility endorser yang tinggi (+1SD) dengan $(B=-0,613 ; S E=0,291 ; Z=-2,11$; $p<0,035)$ memiliki perbedaan yang cukup besar daripada dengan tingkat credibility endorser yang rendah (-1SD) dengan $(B=-0,327 ; S E=0,312 ; Z=-2,11 ; p<0,035)$. Dengan demikian credibility endorser dapat memoderasi pengaruh dimensi entertainment dan trendiness terhadap intensi membeli namun credibility endorser tidak dapat memoderasi pengaruh word of mouth, customization, dan interaction terhadap intensi membeli.

\section{I S K U S I}

Berdasarkan hasil uji regresi berganda ditemukan bahwa social media marketing marketing secara umum menunjukkan nilai signifikansi 0,001 < 0,05 sehingga social media marketing secara umum memiliki pengaruh yang signifikan terhadap intensi membeli produk perawatan kulit pada pria serta social media marketing secara umum memberikan pengaruh sebesar 36\% terhadap intensi membeli produk perawatan kulit pada pria. Maka dari itu, $\mathrm{H}_{1}$ pada penelitian ini dapat diterima. Selain itu, jika dilihat secara partial pengaruh setiap dimensi social media marketing terdapat dua dimensi yang berpengaruh signifikan yaitu entertainment dengan customization. Sedangkan tiga dimensi lainnya yaitu interaction, word of mouth, dan trendiness tidak signifikan.

Hasil yang diperoleh penulis untuk $\mathrm{H}_{1}$ ini sesuai dengan yang disampaikan oleh Mikalef, Ginakof \& Pateli (2012 dalam Moriansyah, 2015) yang mengatakan bahwa pada era digital saat ini, proses pengambilan keputusan konsumen dapat dipengaruhi oleh media sosial, termasuk dalam hal mempengaruhi 
keputusan untuk membeli suatu produk. Media sosial dapat digunakan sebagai sarana untuk mencari informasi bagi konsumen. Hasil $\mathrm{H}_{1}$ pada penelitian ini juga mendukung beberapa penelitian sebelumnya seperti pada penelitian yang dilakukan oleh (Kim \& Ko, 2010) menemukan bahwa social media marketing memiliki pengaruh terhadap intensi membeli produk fashion mewah serta penelitian yang dilakukan oleh (Laksamana, 2018) yang juga menemukan pengaruh social media marketing terhadap intensi membeli pada industri bank di Indonesia.

Berdasarkan analisis moderasi yang telah dilakukan pada hasil penelitian interaction effect pada model 1 yaitu antara credibility endorser dengan entertainment, kemudian pada model 2 antara credibility endorser dengan customization, pada model 3 credibility endorser dengan interaction, model 4 credibility endorser dengan word of mouth, dan model 5 credibility endorser dengan trendiness semuanya tidak signifikan sehingga untuk terjadi efek moderasi sangat kecil. Lalu, dapat dilihat pada hasil simple slope bahwa customization, word of mouth, dan interaction terdapat perbedaan pada tingkat credibility endorser yang rendah (-1SD) maupun tinggi (+1SD) hampir tidak terlalu kelihatan berbeda sehingga $\mathrm{H}_{3}$, $\mathrm{H}_{4}$, dan $\mathrm{H}_{5}$ pada penelitian ini ditolak. Sedangkan pada model 1 dan 5 yaitu entertainment dan trendiness terlihat bahwa pada kondisi tingkat credibility endorser yang tinggi (+1SD) daripada saat tingkat credibility endorser rendah (-1SD) sehingga $\mathrm{H}_{2}$ dan $\mathrm{H}_{6}$ dapat diterima.

$\mathrm{H}_{3}, \mathrm{H}_{4}$, dan $\mathrm{H}_{5}$ pada penelitian ini mengasumsikan bahwa credibility endorser dapat memoderasi pengaruh customization, word of mouth dan interaction pada intensi membeli produk perawatan kulit pada pria. Namun pada penelitian ini peneliti tidak menemukan bukti yang dapat mengkonfirmasi bahwa credibility endorser dapat memoderasi pengaruh baik customization, word of mouth, dan interaction terhadap intensi membeli produk perawatan kulit pada pria. Artinya, baik adanya credibility endorser maupun tidak ada credibility endorser tidak mengubah atau memodifikasi korelasi customization, word of mouth, dan interaction dengan intensi membeli.

Kemudian, untuk $\mathrm{H}_{2}$ dan $\mathrm{H}_{6}$ yaitu pengaruh entertainment dan trendiness terhadap intensi membeli dapat dimoderasi oleh credibility endorser. Dengan adanya credibility endorser dapat memperkuat pengaruh entertainment dan trendiness terhadap intensi membeli produk perawatan kulit pria. Adanya endorser sebagai komunikator yang kredibel dapat membuat konsumen yakin akan produk yang akan mereka beli (Gouranga \& Brajesh, 2011). Adanya endorser dapat menambah unsur entertainment di media sosial dapat lebih menarik konsumen untuk memiliki intensi membeli pada produk perawatan kulit pria. Kemudian hadirnya endorser dapat menambah kesan tren atau baru terhadap produk sehingga dapat meningkatkan minat beli dari konsumen.

\section{S I M P U L A N}

Berdasarkan hasil penelitian, dapat disimpulkan bahwa social media marketing secara umum memiliki pengaruh yang signifikan terhadap intensi membeli produk perawatan kulit pada pria. Kemudian, credibility endorser dapat memoderasi pengaruh dimensi entertainment dan trendiness namun credibility endorser tidak dapat memoderasi pengaruh dimensi customization, word of mouth, dan interaction terhadap intensi membeli produk perawatan kulit pada pria.

Selanjutnya, saran untuk penelitian selanjutnya yaitu dapat membandingkan pengaruh social media marketing terhadap intensi membeli antara subjek pria dan wanita. Kemudian, penelitian selanjutnya juga dapat meneliti dengan memberikan beberapa kriteria bagi endorser seperti jenis kelamin endorser, jumlah followers di media sosia; , atau dapat membandingkan pengaruh celebrity endorser dengan influencer endorsment atau non-celebrity endorser. 
Saran bagi perusahaan atau organisasi yaitu dalam upaya memaksimalkan target penjualan, media sosial dapat menjadi sarana efektif dalam menjual, mengiklankan, serta mempromosikan produk. Perusahaan dapat memberikan paparan mengenai informasi produk di media sosial serta dapat berinteraksi dengan konsumen melalui media sosial. Selain itu, perusahaan juga dapat menggunakan jasa endorser di media sosial untuk menambah unsur entertainment dan kesan tren atau baru sehingga dapat meningkatkan minat beli konsumen. Dalam hal memilih endorser, perusahaan dapat memilih seorang endorser yang kredibel yang tidak hanya menarik (attractiveness), namun juga memiliki pengetahuan dan pengalaman (expertise) dan kepercayaan (trustworthiness).

\section{U C A P A N TERIMAKASIH}

Terimakasih kepada Tuhan Yang Maha Kuasa, seluruh partisipan penelitian, serta seluruh pihak yang membantu proses penulisan dan penyelesaian penelitian ini. Semoga penelitian ini dapat memberikan wawasan dan pengetahuan yang baru mengenai perilaku membeli konsumen.

\section{DEKLARASI POTENSI TERJADINYA KONFLIK KEPENTINGAN}

Rafael Hans Christian dan Dewi Syarifah tidak bekerja, menjadi konsultan, memiliki saham, atau menerima dana dari perusahaan atau organisasi manapun yang mungkin akan mengambil untung dari diterbitkannya naskah ini.

\section{P UST AKA ACUAN}

Abbas, A. (2017). The Beauty and Personal Care Market: Global and Regional Overview. Beautyworld $\begin{array}{llllll}\text { Middle } \quad \text { East, } & \text { May }\end{array}$ https://www.beautyworldme.com/uploads/editor_images/file/beautyworld17/amna.pdf

Ajzen, I. (1991). The theory of planned behavior. Organizational Behavior and Human Decision Processes, 50(2), 179-211. https://doi.org/10.1016/0749-5978(91)90020-T

Bilgin, Y. (2018). The effect of social media marketing activities on brand awareness, brand image and brand loyalty. Business \& Management Studies: An International Journal, 6(1), 128-148. https://doi.org/10.15295/bmij.v6i1.229

Choi, S. M., \& Rifon, N. J. (2012). It Is a Match: The Impact of Congruence between Celebrity Image and Consumer Ideal Self on Endorsement Effectiveness. Psychology and Marketing, 29(9), 639-650. https://doi.org/10.1002/mar.20550

Goldsmith, R. E., Lafferty, B. A., \& Newell, S. J. (2000). The impact of corporate credibility and celebrity credibility on consumer reaction to advertisements and brands. Journal of Advertising, 29(3), 4354. https://doi.org/10.1080/00913367.2000.10673616

Gouranga, P. \& Brajesh, K. (2011). Celebrity Endorsement in FMCGs Advertising -A Case Study in a Culturally Vibrant Society. Advances In Management, 4(8), 24-28. https://ideas.repec.org/a/mgn/journl/v4y2011i8a4.html

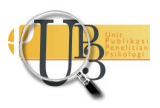


Herdiyanti, N., \& Titus, A. (2013). Research on Market Trends and Consumer Behavior in Male Grooming Products (Especially Face Cleanser Category) in Indonesia. The Indonesian Journal of Business Administration, 2(6), 663-671.

Isyanto, P., Sapitri, R. G., \& Sinaga, O. (2020). Micro influencers marketing and brand image to purchase intention of cosmetic products focallure. Systematic Reviews in Pharmacy, 11(1), 601-605. https://doi.org/10.5530/srp.2020.1.75

Kim, A. J., \& Ko, E. (2010). Impacts of luxury fashion brand's social media marketing on customer relationship and purchase intention. Journal of Global Fashion Marketing, 1(3), 164-171. https://doi.org/10.1080/20932685.2010.10593068

Kotler, P., \& Keller, K. L. (2016). A framework for marketing management (p. 352). Boston, MA: Pearson.

Laksamana, P. (2018). International review of management and marketing impact of social media marketing on purchase intention and brand loyalty: Evidence from Indonesia's banking industry. International Review of Management and Marketing, 8(1), 13-18. http:www.econjournals.com

Man, Q., \& Rahman, J. M. (2019). The impact of cosmetics industry social media marketing on brand loyalty: Evidence from chinese college students. Academy of Marketing Studies Journal, 23(2).

Mittelstaedt, J. D., Riesz, P. C., \& Burns, W. J. (2000). Why are endorsements effective? Sorting among theories of product and endorser effects. Journal of Current Issues and Research in Advertising, 22(1), 55-65. https://doi.org/10.1080/10641734.2000.10505101

Moriansyah, L. (2015). Pemasaran Melalui Media Sosial : Antecedents Dan Consequences Social Media Marketing : Antecedents and Consequenc-es. Penelitian Komunikasi Dan Opini Publik, 187-196.

Ohanian, R. (1990). Construction and validation of a scale to measure celebrity endorsers' perceived expertise, trustworthiness, and attractiveness. Journal of Advertising, 19(3), 39-52. https://doi.org/10.1080/00913367.1990.10673191

Puspasari, C.M.A., Aprilianty, A. (2019). Factors Affecting Consumer Purchase Behavior Towards Men Skincare Products in Indonesia. School of Business and Management, Institut Teknologi Bandung, Indonesia, August, 7-9. https://core.ac.uk/download/pdf/324148451.pdf

Ridwan, A. F., Maulina, E., \& Chan, A. (2017). Comparisons of Factors that Influence Male Consumer Behavior in Purchasing Skin Care Products (Case Study: Men from Suwon City, South Korea and Bandung, Indonesia). Review of Integrative Business and Economics Research, 6, 176.

Sanny, L., Arina, A. N., Maulidy, R. T., \& Pertiwi, R. P. (2020). Purchase intention on Indonesia male's skin care by social media marketing effect towards brand image and brand trust. Management Science Letters, 10(10), 2139-2146. https://doi.org/10.5267/j.msl.2020.3.022

Saravanakumar, M., \& SuganthaLakshmi, T. (2012). Social media marketing. Life Science Journal, 9(4), 4444-4451.

Soesatyo, N., \& Rumambi, L. J. (2013). Analisa Credibility Celebrity Endorser Model: Sikap Audience

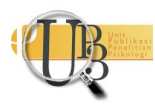


Terhadap Iklan dan Merek serta Pengaruhnya Pada Minat Beli "Top Coffee." Jurnal Manajemen Pemasaran, 1(2), 1-12. http://publication.petra.ac.id/index.php/manajemenpemasaran/article/view/500

Stafford, M. R., Stafford, T. F., \& Day, E. (2002). A contingency approach: The effects of spokesperson type and service type on service advertising perceptions. Journal of Advertising, 31(2), 17-35. https://doi.org/10.1080/00913367.2002.10673664

Tatar, Ş. B., \& Eren-Erdoğmuş, İ. (2016). The effect of social media marketing on brand trust and brand loyalty for hotels. Information Technology and Tourism, 16(3), 249-263. https://doi.org/10.1007/s40558-015-0048-6 